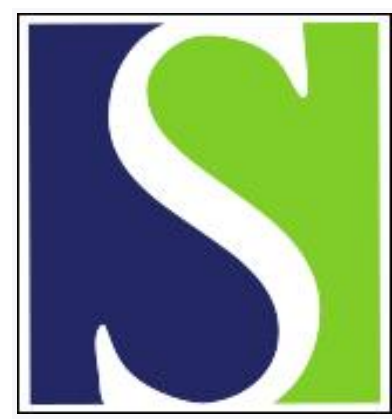

Scand J Work Environ Health 2003;29(2):152-158

https://doi.org/10.5271/sjweh.717

Issue date: Apr 2003

Effects of thermal degradation products from polyurethane foams based on toluene diisocyanate and diphenylmethane diisocyanate on isolated, perfused lung of guinea pig

by Låstbom L, Colmsjö A, Johansson R, Karlsson D, Melin J, Nordqvist Y, Skarping $\mathrm{G}$

Affiliation: Karolinska Institutet, Institute of Environmental Medicine, Division of Inhalation Toxicology, PO Box 210, SE-17177 Stockholm, Sweden. lena.lastbom@imm.ki.se

Key terms: aerosol; diphenylmethane diisocyanate; guinea pig; isolated lung; methyl isocyanate; mineral wool; perfused lung; phenyl isocyanate; polyurethane foam; thermal degradation product; toluene diisocyanate

This article in PubMed: www.ncbi.nlm.nih.gov/pubmed/12718501 


\title{
Effects of thermal degradation products from polyurethane foams based on toluene diisocyanate and diphenylmethane diisocyanate on isolated, perfused lung of guinea pig
}

\author{
by Lena Låstbom, PhD, ${ }^{1}$ Anders Colmsjö, PhD, ${ }^{2}$ Rolf Johansson, ${ }^{2}$ Daniel Karlsson, PhD, ${ }^{3}$ \\ Jens Melin, PhD, ${ }^{2,4}$ Yvonne Nordqvist, BSc, ${ }^{2}$ Gunnar Skarping, PhD ${ }^{3}$
}

\begin{abstract}
Låstbom L, Colmsjö A, Johansson R, Karlsson D, Melin J, Nordqvist Y, Skarping G. Effects of thermal degradation products from polyurethane foams based on toluene diisocyanate and diphenylmethane diisocyanate on isolated, perfused lung of guinea pig. Scand J Work Environ Health 2003;29(2):152-158.

Objectives The composition of thermal degradation products from two types of polyurethane foams, one based on toluene diisocyanate (TDI) and the other on diphenylmethane diisocyanate (MDI), was analyzed and their toxic lung effects were compared.

Methods Isolated perfused lungs of guinea pig were subjected to thermal decomposition products of polyurethane foams from an aerosol generator with compartments for diluting, mixing, and sampling.

Results Thermal degradation of MDI-based polyurethane foams released MDI, phenyl isocyanate, and methyl isocyanate. The emitted particulate fraction was $75 \%$ for MDI, whereas that for TDI from TDI-based polyurethane foam was 3\%. Thermal degradation products from MDI-based foam caused a pronounced dosedependent decrease in the measured lung function parameters (conductance and compliance). In contrast, the thermal degradation products from TDI-based foam did not cause any decrease in lung function.

Conclusions Thermal degradation products generated from MDI-based polyurethane foam were more toxic to the lung than those generated from TDI-based polyurethane foam. This difference was probable due to MDI in the particle phase.
\end{abstract}

Key terms aerosol, methyl isocyanate, mineral wool, phenyl isocyanate.

Today, enormous quantities of monomer and oligomer diisocyanates are used in industry to produce polyurethanes. Products containing isocyanates (eg, adhesives, paints, plastics, synthetic rubber, and rigid and elastic foams) can be found everywhere in the environment. When polyurethanes are heated, isocyanates and other thermal degradation products are released (1-5). Isocyanates are irritating to the respiratory tract (6-10) and are known as the most common cause of occupational asthma (11). They can sensitize workers and can cause severe asthma attacks even when workers are exposed to concentrations far below the occupational exposure limits $(1,12)$. Due to the extensive use of poly- urethanes, and therefore the extensive exposure of workers (eg, firemen, pipelayers, people working with the shaping of plastics containing polyurethane, and welders working with painted metal sheeting), there is much interest in the composition and toxicity of their thermal degradation products.

Using a perfused lung system, we had earlier performed several toxicology and mechanistic studies with pure isocyanates, such as toluene diisocyanate (TDI) and hexamethylene diisocyanate (HDI) (13-15). Since our results during a study with radioactive TDI were analogous to those obtained in vivo, we concluded that the isolated perfused lung model was a very useful tool

1 Karolinska Institutet, Stockholm, Sweden.

2 Stockholm University, Stockholm, Sweden.

3 Lund University, Lund, Sweden.

4 Göteborg University, Göteborg, Sweden.

Reprint requests to: Dr Lena Låstbom, Karolinska Institutet, Institute of Environmental Medicine, Division of Inhalation Toxicology, Box 210, SE-171 77 Stockholm, Sweden. [E-mail: lena.lastbom@imm.ki.se] 
for studying the effects of isocyanates (16). Therefore, in order to evaluate the acute toxic effect of the thermal degradation products of polyurethanes, we generated aerosols similar to those found in workplaces and exposed an isolated lung system from a guinea pig to their degradation products. We chose to work with two kinds of polyurethane foams, one based on TDI and the other on diphenylmethane diisocyanate (MDI). Unifying these two rather complex systems, the aerosol generator and the isolated perfused lung setup made it possible to study the composition of the aerosols formed during the thermal degradation of TDI- and MDI-based polyurethane foams and to compare the acute lung effects caused by the degradation products.

\section{Subjects and methods}

\section{Materials}

The TDI-based polyurethane foam consisted of 1-mm thick dishclothes cut in strips $(240 \times 10 \mathrm{~mm})$. The MDIbased polyurethane foam was obtained from materials intended for car seats. It was likewise cut in strips of suitable sizes.

Mineral wool was used to generate test atmospheres containing methyl isocyanate (MIC). In this study we used the following three kinds of mineral wool: type A with $7 \%$ binder and a density of $35 \mathrm{~kg} / \mathrm{m}^{3}$, type B with $1.8 \%$ binder and a density of $130 \mathrm{~kg} / \mathrm{m}^{3}$, and type $\mathrm{C}$ with $2.9 \%$ binder and a density of $30 \mathrm{~kg} / \mathrm{m}^{3}$.

\section{Generation of the test atmosphere}

To generate the thermal degradation aerosols, we used a system developed by Melin et al (figure 1) (2). The TDI-based foam strips were burned at $300^{\circ} \mathrm{C}$, whereas, $350^{\circ} \mathrm{C}$ or $450^{\circ} \mathrm{C}$ was used for the MDI-based strips. A stream of preheated combustion air $(0.5 \mathrm{l} / \mathrm{min})$ was passed through the furnace, and it transported the combustion products to a heated manifold into which diluting air (25 l/min) was added. Thereafter the air and its components were directed to a mixing compartment. Only a small part of the total air stream was directed to the perfused guinea pig lung. The air was room temperature by the time it reached the lung. All the tubes were made of Teflon ${ }^{\mathrm{TM}}$.

Phenyl isocyanate $(\mathrm{PhI})$ vapor was generated by directing a stream of air through a nozzle against the surface of liquid $\mathrm{PhI}$ in a vial placed in a cooling block. The vapor outflow through a tube in the glass vial was then diluted and mixed in a mixing tower. Lungs were exposed as in the polyurethane experiments. The conditions for the experiments were a generator airflow of
$0.1 \mathrm{l} / \mathrm{min}$ and a diluting airflow of $25 \mathrm{l} / \mathrm{min} ; 1 \mathrm{ml}$ of $\mathrm{PhI}$ was kept at $0.5^{\circ} \mathrm{C}$ in the vial.

Mineral wool often contains a urea-based binder, which, upon heating, releases MIC. In order to obtain the degradation products of the binder components of the mineral wool, we used the same equipment that generated the thermal degradation products of the polyurethane foam. The temperature chosen for these experiments was $300^{\circ} \mathrm{C}$, except for one experiment with sample $\mathrm{B}$, which was conducted at $350^{\circ} \mathrm{C}$. The content of the urea-based binder in the mineral wool is important with respect to the MIC concentrations generated. The densities of mineral wool cannot generally be correlated with its binder content.

\section{Sampling of isocyanates in the generated test atmospheres}

Two simultaneous air samples were taken in periods that varied between 2 and 5 minutes, starting at the beginning of the lung exposure. New samples were taken periodically every 15 minutes until the end of the exposure. The sampling flow rate was set to $1.0 \mathrm{l} / \mathrm{min}$. The samples were collected in impinger flasks containing 10 $\mathrm{ml}$ of $0.01 \mathrm{M}$ dibutylamine (DBA) in toluene (17). In two experiments the particles escaping the impinger flasks, smaller than $1.5 \mu \mathrm{m}$ (18), were collected on

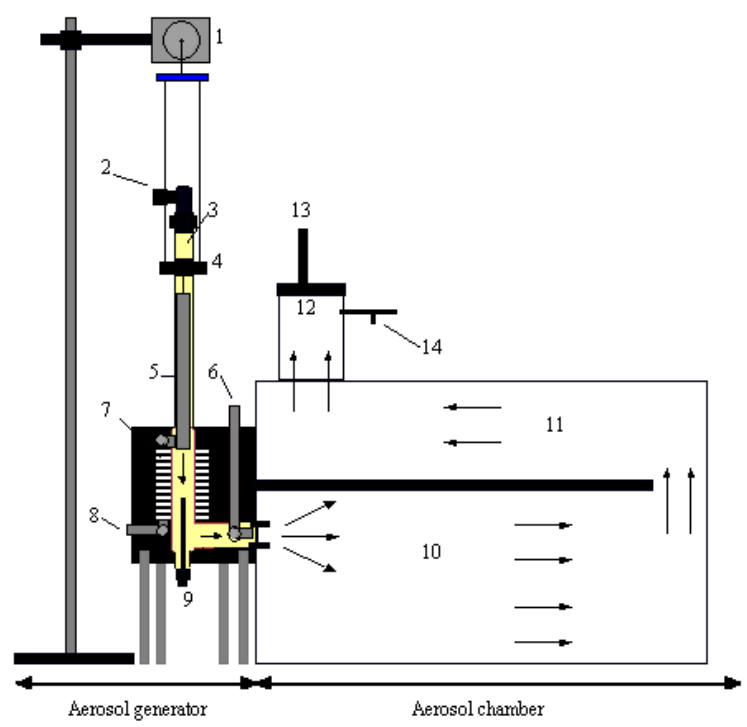

Figure 1. Schematic drawing of the aerosol generator system. (1= geared electric motor, 2 = flushing port for nitrogen, 3 = holder tube for quartz sample, 4 = suspended magnets, $5=$ sample strip, $6=$ diluting air, 7 = furnace, $8=$ combustion gas, $9=$ thermocouple, $10=$ mixing compartment, 11 = equilibrium compartment, 12 = sampling tower, 13 = exhaust, 14 = outlet for exposure) 
13-mm glass-fiber filters in polypropylene filter holders. Immediately after the exposure, the glass-fiber filters were transferred to vials containing $10 \mathrm{ml}$ of toluene.

\section{Determination of toluene diisocyanate in air samples}

The TDI-DBA derivatives were analyzed with a highperformance liquid chromatographic (HPLC) system equipped with an ultraviolet detector with the wavelength set at $240 \mathrm{~nm}$. The mobile phase was $80 \%$ acetonitrile and $20 \%$ water. The column was $10-\mathrm{cm} \mathrm{C-18}$ with $5-\mu \mathrm{m}$ particles, and the flow rate was $1.0 \mathrm{ml} / \mathrm{min}$.

\section{Determination of diphenylmethane diisocyanate, phenyl isocyanate and methyl isocyanate in the air samples}

The sampling solutions and standard solutions were spiked with deuterium-labeled isocyanate-DBA derivatives (internal standards). The solutions were evaporated to dryness and dissolved in $0.5 \mathrm{ml}$ of acetonitrile. The solutions were then injected into a liquid chromatograph-mass spectrometer. The mass spectrometer was working in the electrospray mode, monitoring positive ions, and was connected to a Phoenix $40 \mathrm{mi}-$ cro-LC pump. Injections were made with a CMA/200 autosampler. The isocyanate-DBA derivatives were analyzed using linear gradient elution for 30 minutes with a mobile phase of acetonitrile:water (from 50:50\% to 95:5\% volume/volume) and $0.05 \%$ formic acid with a flow rate of $40 \mu \mathrm{l} / \mathrm{min}$. The used liquid chromatographic column was Hypersil C18 $(150 \times 1.0 \mathrm{~mm}$, with $5 \mu \mathrm{m}$ particles).

\section{Isolated perfused lungs of guinea pigs}

Lung preparations from guinea pigs of the Dunkin-Hartley strain and weighing 400-600 grams were used. The animals were anesthetized with pentobarbital (Mebumalum Vet, Nord Vacc, Sweden), $120 \mathrm{mg} / \mathrm{kg}$ being injected intraperitoneally. The lungs were then surgically removed as described by Kröll et al (19) and perfused with the same buffer and under the same conditions as described by Låstbom et al (20). Once suspended in the thoracic chamber, the lungs were ventilated at 60 breaths/minute by creating an alternating negative pressure $(-0.32$ to $-0.58 \mathrm{kPa})$ inside the thoracic chamber using an animal respirator (model 7025, Ugo Basile, Biological Research Apparatus, Varese, Italy) and a vacuum source connected to the thoracic chamber. The tracheal airflow was measured with a heated pneumotachograph (Hans Rudolf Inc, Kansas City, MO, USA). Via laboratory instrument system architecture (LISA, Astrazeneca, Lund, Sweden), pulmonary pressure, together with tracheal airflow, was monitored and recorded directly on a computer, on which calculations of lung conductance $\left(\mathrm{G}_{\mathrm{aw}}\right)$ and dynamic compliance $\left(\mathrm{C}_{\mathrm{dyn}}\right)$ were performed (21). Lung conductance is a measurement of how easy the air moves in the upper airways, and lung compliance is a measurement of the elasticity of the lower part of the lung. The perfusion flow was measured manually.

The lungs were allowed to stabilize for 20 minutes with single-pass perfusion buffer containing albumin before the experiment was started. Only lung preparations with stable baseline values for perfusion flow, conductance, and compliance were used. The values for conductance and compliance were 72.8 (SD 16.9) $\mathrm{ml} /(\mathrm{s} \cdot \mathrm{kPa})$ and $8.2(\mathrm{SD} 2.7) \mathrm{ml} / \mathrm{kPa}$, respectively, and the perfusion flow was 30 (SD 5.0) $\mathrm{ml} / \mathrm{min}(\mathrm{N}=28)$. Before the exposure the lungs were allowed to equilibrate for 10 minutes in 150 milliliters of recirculating KrebsRinger buffer containing $2 \%$ albumin.

The lung preparation was exposed to normal air for 10 minutes and then exposed via the air passage for up to 30 minutes to $\mathrm{PhI}$ or thermal degradation products. The pneumotachograph was taken away during the exposure and put back every 15 minutes in order to obtain the conductance and compliance values.

\section{Results}

When the MDI-based polyurethane foam was heated, not only was MDI released, but also $\mathrm{PhI}$ and MIC. As seen in table 1, there was an increasing formation of the three isocyanates, of which MDI and MIC correlated significantly with the increasing mass feeding rate of the polyurethane foam (MDI: $\mathrm{F}=11.6, \mathrm{r}=0.75$; $\mathrm{MIC}$ : $\mathrm{F}=24.4$, $\mathrm{r}=0.93$; $\mathrm{F}$ and $\mathrm{r}$ denotes goodness of fit and the correlation coefficient, respectively). In experiments 10 and 11 , in which the temperature was $350^{\circ} \mathrm{C}$, both gaseous and particulate isocyanates were sampled in contrast to the experiments conducted at $450^{\circ} \mathrm{C}$, when only gaseous isocyanates were sampled.

The particulate MDI measured at $350^{\circ} \mathrm{C}$ amounted to about $75 \%$ of the total MDI content. The gaseous isocyanate content did not differ between the experiments conducted at $350^{\circ} \mathrm{C}$ and $450^{\circ} \mathrm{C}$.

From the TDI-based foam, degraded at $300^{\circ} \mathrm{C}$, both 2,4-TDI and 2,6-TDI were formed; the total values are presented in table 2 .

We compared the acute toxic lung effects of the thermal degradation products from the two types of polyurethane foams, one based on TDI and the other on MDI. Thermal degradation products from MDI-based polyurethane foam caused a dose-dependent decrease in such lung function parameters as conductance and compliance (table 1 and figure 2). There were no clear signs 
Table 1. Concentrations of isocyanates in the air samples taken during lung exposure to the thermal degradation products of MDIbased polyurethane foam $(\mathrm{N}=11)$. ( $P U F=$ polyurethane foam, $\mathrm{MDI}=$ diphenylmethane diisocyanate, $\mathrm{Phl}=$ phenyl isocyanate, $\mathrm{MIC}=$ methyl isocyanate, $\mathrm{CV}=$ coefficient of variation, Temp $=$ temperature, Conc $=$ concentration, $\cdot=$ not applicable, $\cdot \cdot=$ not analyzed)

\begin{tabular}{|c|c|c|c|c|c|c|c|c|c|c|c|c|c|c|c|c|}
\hline \multirow[t]{3}{*}{ Experiment } & \multirow{3}{*}{$\begin{array}{c}\text { Temp } \\
\left({ }^{\circ} \mathrm{C}\right)\end{array}$} & \multirow{3}{*}{$\begin{array}{l}\text { Mass } \\
\text { feeding } \\
\text { rate of PUF } \\
(\mathrm{mg} / \mathrm{min})\end{array}$} & \multicolumn{6}{|c|}{ MDI } & \multicolumn{6}{|c|}{$\mathrm{Phl}$} & \multirow{2}{*}{\multicolumn{2}{|c|}{$\frac{\text { MIC }}{\text { Total }(N=6)}$}} \\
\hline & & & \multicolumn{2}{|c|}{$\begin{array}{l}\text { Particle phase } \\
(\mathrm{N}=4)\end{array}$} & \multicolumn{2}{|c|}{$\begin{array}{l}\text { Gas phase } \\
\mathrm{N}=6)\end{array}$} & \multicolumn{2}{|c|}{ Total $(\mathrm{N}=4)$} & \multicolumn{2}{|c|}{$\begin{array}{l}\text { Particle phase } \\
(\mathrm{N}=4)\end{array}$} & \multicolumn{2}{|c|}{$\begin{array}{l}\text { Gas phase } \\
(\mathrm{N}=6)\end{array}$} & \multicolumn{2}{|c|}{ Total $(\mathrm{N}=4)$} & & \\
\hline & & & $\begin{array}{l}\text { Conc } \\
\text { (ppb) }\end{array}$ & $\begin{array}{l}\text { CV } \\
(\%)\end{array}$ & $\begin{array}{l}\text { Conc } \\
\text { (ppb) }\end{array}$ & $\begin{array}{l}\text { CV } \\
(\%)\end{array}$ & $\begin{array}{l}\text { Conc } \\
\text { (ppb) }\end{array}$ & $\begin{array}{l}\text { CV } \\
(\%)\end{array}$ & $\begin{array}{l}\text { Conc } \\
\text { (ppb) }\end{array}$ & $\begin{array}{l}\text { CV } \\
(\%)\end{array}$ & $\begin{array}{l}\text { Conc } \\
\text { (ppb) }\end{array}$ & $\begin{array}{l}\text { CV } \\
(\%)\end{array}$ & $\begin{array}{l}\text { Conc } \\
\text { (ppb) }\end{array}$ & $\begin{array}{l}\text { CV } \\
(\%)\end{array}$ & $\begin{array}{l}\text { Conc } \\
\text { (ppb) }\end{array}$ & $\begin{array}{l}\text { CV } \\
(\%)\end{array}$ \\
\hline 1 & 450 & 4.5 & .. & .. & 2.0 & 38.1 & . & . & .. & .. & 16.7 & 32.8 & . & . & .. & .. \\
\hline 2 & 450 & 5.1 & .. & .. & 1.7 & 60.5 & . & . & .. &.. & 23.0 & 91.7 & . & . & .. & .. \\
\hline 3 & 450 & 5.1 & .. & .. & 8.9 & 38.2 & . & . & .. &.. & 75.8 & 32.6 & . & . & 0.0 & 0.0 \\
\hline 4 & 450 & 5.5 & .. & .. & 4.6 & 132 & . & . & .. &.. & 45.1 & 62.8 & . & . & 0.6 & 245 \\
\hline 5 & 450 & 16.9 & .. &.. & 7.6 & 35.2 & . & . & .. &.. & 56.5 & 38.9 & . & . & .. &.$\cdot$ \\
\hline 6 & 450 & 17.7 & .. & .. & 9.5 & 70.5 & . & . & .. &.. & 68.9 & 78.1 & . & . & 16.2 & 51 \\
\hline 7 & 450 & 19.3 & .. & .. & 10.2 & 60.4 & . & . & .. &.. & 65.2 & 103 & . & . &.. &.. \\
\hline 8 & 450 & 19.7 & .. & .. & 12.0 & 93.7 & . & . & .. &.. & 70.9 & 65.7 & . & . & 25.2 & 100 \\
\hline 9 & 450 & 20.4 & .. & .. & 10.7 & 56.9 & . & . & .. &.. & 83.4 & 42.0 & . & . &.. & .. \\
\hline 10 & 350 & 16.2 & 33.8 & 8.2 & 14.2 & 45.1 & 48.0 & 18.5 & 4.8 & 40.4 & 231.0 & 45.6 & 235.8 & 46.3 & 28.3 & 27.4 \\
\hline 11 & 350 & 18.8 & 34.7 & 4.2 & 7.9 & 47.5 & 42.6 & 12.4 & 5.8 & 41.1 & 52.5 & 16.7 & 58.3 & 18.6 & 24.1 & 27.4 \\
\hline
\end{tabular}

of edema in the lungs exposed to MDI-based polyurethane foam (data not shown).

In figure 3 , the concentration of $\mathrm{MDI}$ is four times higher at $350^{\circ} \mathrm{C}$ than at $450^{\circ} \mathrm{C}$ because both particulate and gaseous isocyanates were sampled in the former case, whereas only gaseous isocyanates were determined in the latter. Consequently, the same bronchoconstriction was obtained at both $350^{\circ} \mathrm{C}$ and $450^{\circ} \mathrm{C}$. The thermal degradation products from TDI-based polyurethane foam did not cause any decrease in lung function.
Table 2. Concentrations of isocyanates in the air samples taken during lung exposure to TDI-based polyurethane foam $(\mathrm{N}=6)$. (TDI = toluene diisocyanate, PUF = polyurethane foam, CV = coefficient of variation)

\begin{tabular}{lcccc}
\hline Experiment & $\mathrm{N}$ & $\begin{array}{c}\text { Mass feeding rate of PUF } \\
(\mathrm{mg} / \mathrm{min})\end{array}$ & $\begin{array}{c}\text { TDI } \\
(\mathrm{ppb})\end{array}$ & $\begin{array}{c}\mathrm{CV} \\
(\%)\end{array}$ \\
\hline 1 & 8 & 6.2 & 1100 & 8.0 \\
2 & 6 & 6.3 & 996 & 4.2 \\
3 & 8 & 6.5 & 812 & 25.7 \\
4 & 8 & 6.6 & 765 & 28.5 \\
5 & 8 & 9.7 & 1130 & 17.8 \\
6 & 6 & 10.0 & 1240 & 34.8 \\
\hline
\end{tabular}
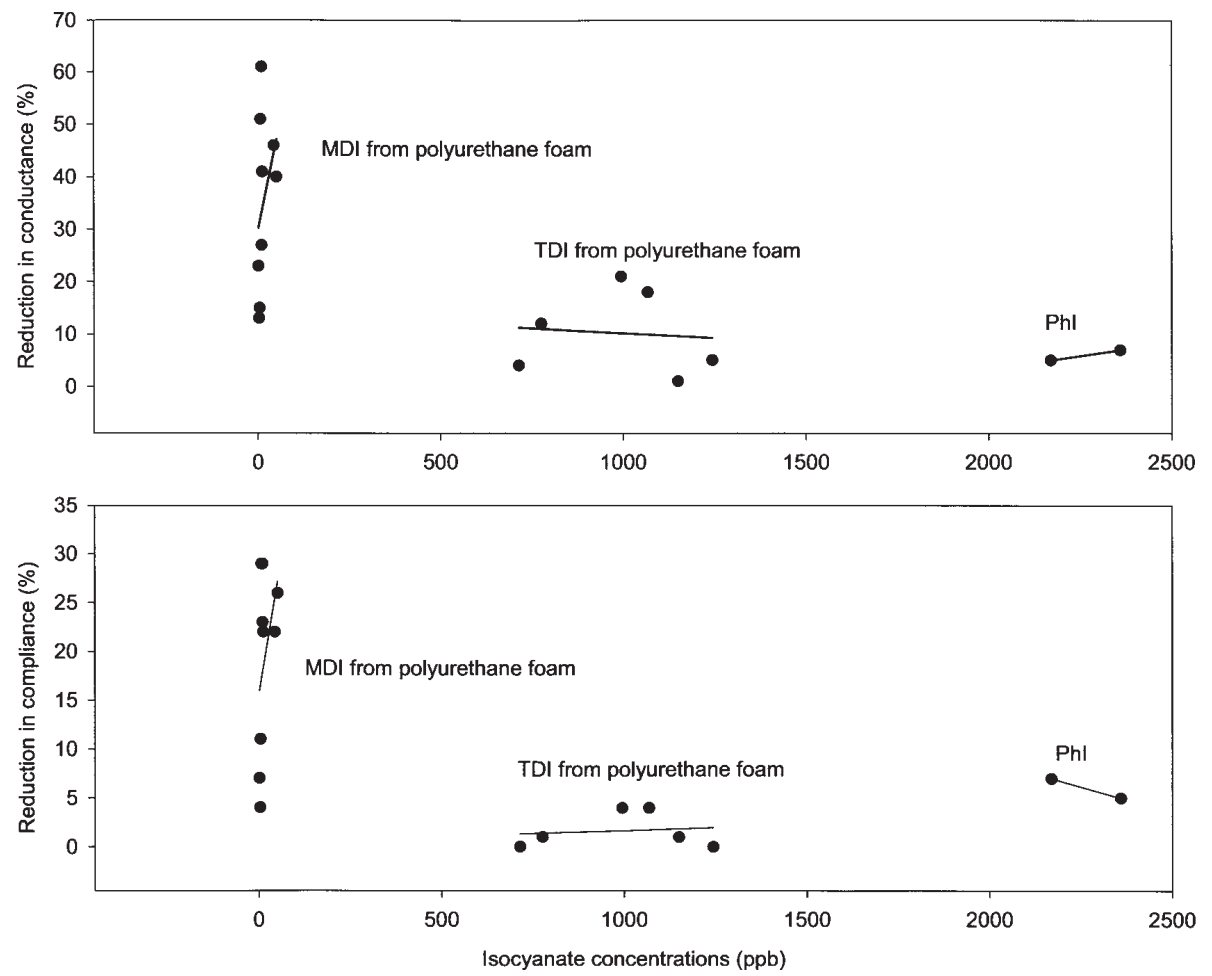

Figure 2. Reduction in the conductance and compliance of the lung function parameters after 30 minutes of exposure to air containing thermal degradation products from MDI-based polyurethane foam $(\mathrm{N}=9)$, TDIbased polyurethane foam $(\mathrm{N}=6)$, or pure phenyl isocyanate (Phl) $(\mathrm{N}=2)$. Every point represents values of conductance or compliance from one experiment after 30 minutes of exposure. (MDI = diphenylmethane diisocyanate, TDI = toluene diisocyanate) 

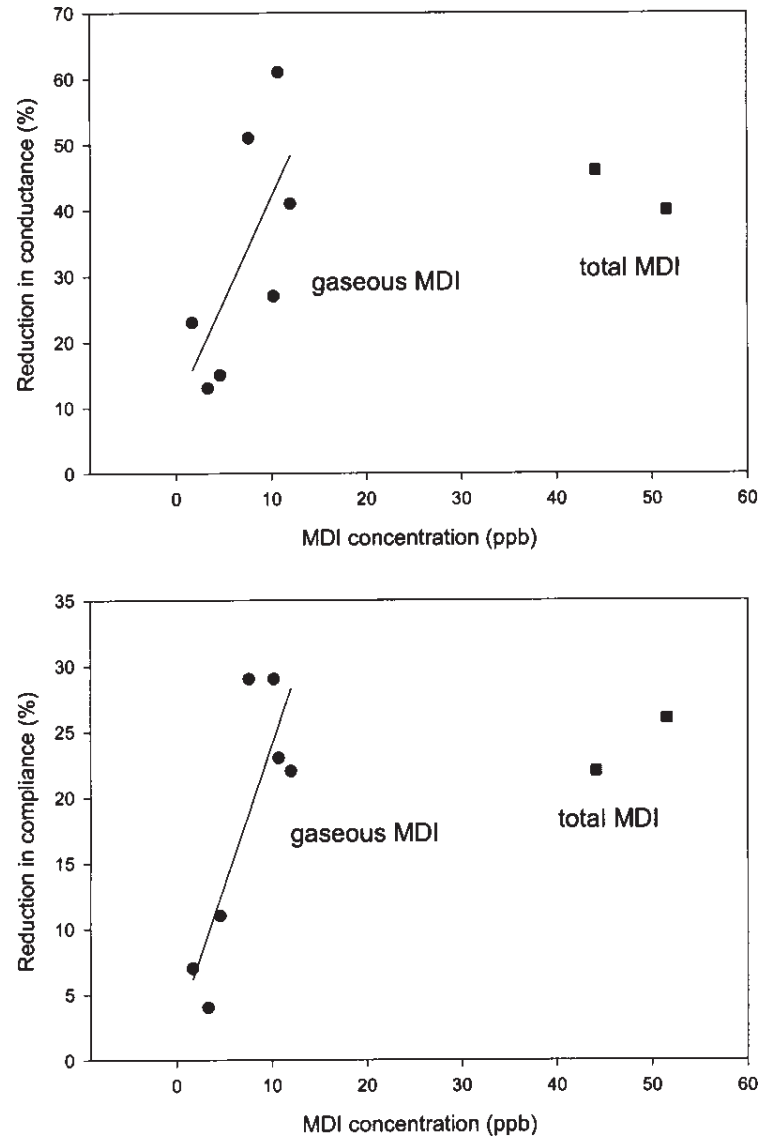

Figure 3. Reduction in the conductance and compliance of the lung function parameters after 30 minutes of exposure to air containing thermal degradation products from MDI-based polyurethane foam heated to $350^{\circ} \mathrm{C}(\mathrm{N}=2)$ or $450^{\circ} \mathrm{C}(\mathrm{N}=7)$. The experiments conducted at $350^{\circ} \mathrm{C}$ show the total MDI concentrations, including both particulate and gaseous $\mathrm{MDI}$, whereas the experiments at $450^{\circ} \mathrm{C}$ show only the gaseous MDI. (MDI = diphenylmethane diisocyanate)

Table 3. Generation of phenyl isocyanate (Phl) from evaporation $(\mathrm{N}=3)$. (CV = coefficient of variation)

\begin{tabular}{llll}
\hline Experiment & $\mathrm{N}$ & $\begin{array}{l}\mathrm{Phl} \\
(\mathrm{ppb})\end{array}$ & $\begin{array}{l}\mathrm{CV} \\
(\%)\end{array}$ \\
\hline 1 & 4 & 2360 & 11.4 \\
2 & 4 & 2170 & 5.3 \\
3 & 4 & 2250 & 6.5 \\
\hline
\end{tabular}

Lungs were exposed to plain $\mathrm{PhI}$ vapor in order to determine whether $\mathrm{PhI}$ was the cause of lung function impairment during exposure to degradation products from MDI-based polyurethane foam. The generated $\mathrm{PhI}$ concentrations are presented in table 3. However, $\mathrm{PhI}$ did not decrease conductance and compliance to the same degree as the thermal degradation products from MDI-based polyurethane foam, even if 10 times higher concentrations of pure $\mathrm{PhI}$ were used than the $\mathrm{PhI}$
Table 4. Concentrations of methyl isocyanate (MIC) in the air samples taken during lung exposure to thermal degradation products from mineral wool and the resulting reduction in lung conductance $(\mathrm{N}=7)$. (Temp = temperature, $\mathrm{CV}=$ coefficient of variation)

\begin{tabular}{lcccccc}
\hline $\begin{array}{l}\text { Mineral } \\
\text { wool }\end{array}$ & $\begin{array}{c}\text { Samples } \\
(\mathrm{N})\end{array}$ & $\begin{array}{l}\text { Binder mass } \\
\text { feeding rate } \\
(\mathrm{mg} / \mathrm{min})\end{array}$ & $\begin{array}{c}\text { Temp } \\
\left({ }^{\circ} \mathrm{C}\right)\end{array}$ & $\begin{array}{l}\mathrm{MIC} \\
(\mathrm{ppb})\end{array}$ & $\begin{array}{l}\mathrm{CV} \\
(\%)\end{array}$ & $\begin{array}{c}\text { Reduction in } \\
\text { conductance } \\
(\%)\end{array}$ \\
\hline Type A & 5 & 0.91 & 300 & 332 & 22.4 & 1 \\
Type A & 5 & 1.0 & 300 & 226 & 17.9 & 7 \\
Type A & 5 & 1.7 & 300 & 480 & 22.7 & 5 \\
Type B & 5 & 1.2 & 300 & 293 & 14.2 & 3 \\
Type B & 5 & 1.0 & 350 & 443 & 19.8 & 0 \\
Type C & 5 & 0.53 & 300 & 145 & 66.9 & 20 \\
Type C & 5 & 0.37 & 300 & 107 & 23.3 & 0 \\
\hline
\end{tabular}

released during the heating of MDI-based polyurethane foam (figure 2).

During the heating of MDI-based polyurethane foam, MIC was formed along with MDI and PhI. Therefore we made some additional and comparative experiments. Thus three different types of mineral wool were used to generate MIC. The results in table 4 show that MIC, in concentrations up to about $500 \mathrm{ppb}$, had no acute effect on lung conductance.

\section{Discussion}

In this study we used a system for generating isocyanate aerosols that are similar in composition to those found in workplaces (2). The system was connected to an isolated perfused lung model that allowed us to measure lung function at different concentrations of isocyanates in air. When the chemical bonds of polyurethane foam break up during heating, several isocyanates, carbon monoxide, hydrogen cyanide, and particles are formed. We measured the concentration of some of the important isocyanates released during the heating of polyurethane foams.

The thermal degradation products from MDI-based polyurethane foam, including MDI, PhI, and MIC, caused a dose-dependent decrease in lung function. In contrast, the thermal degradation products from TDIbased polyurethane foam did not seem to affect lung function. Despite a TDI concentration that was up to 150 times higher than that of released MDI, the degradation products from TDI-based polyurethane foam had no acute effect on lung function. When isolated perfused lungs from guinea pigs were exposed to $\mathrm{PhI}$ in our experiments, we observed no effect on lung function. Pauluhn et al (22) reported chronic airway inflammation in rats exposed to PhI. The concentrations used were similar to ours although the rats were exposed for 2 weeks (6 hours/day), whereas our study of acute effects used 
only 30 minutes of exposure. Because neither exposure to pure $\mathrm{PhI}$ concentrations of up to $2400 \mathrm{ppb}$ nor MIC exposures at levels up to $500 \mathrm{ppb}$ caused an acute effect on lung function in experiments with mineral wool, we propose that the bronchoconstriction determined during exposure to thermal degradation products from MDI-based polyurethane foam is caused primarily by MDI. When the effects of different isocyanates are compared, their relative distribution in the gas and particle phases may be important. We found that $75 \%$ of the total MDI concentration emitted during the degradation of MDI-based polyurethane foam was in the particulate phase. Because of their small size, these particles must be sampled on filters connected after an impinger flask. For example, Spanne et al (18) have shown that impingers have low sampling efficiencies for particles with diameters of less than $1.5 \mu \mathrm{m}$. With a likely size range typical of condensation aerosols, the particulate MDI generated in our study had diameters less than about $1.5 \mu \mathrm{m}$ and should have been deposited in both the alveolar and bronchial region (23).

Isocyanates in the form of small particles may be more toxic than gaseous isocyanates because of the deeper penetration of the particles into the lungs. Melin et al (3) previously showed that only about 3\% of total TDI is emitted as particles when TDI-based polyurethane foam is thermally degraded at $300^{\circ} \mathrm{C}$. Thus TDI emitted from TDI-based polyurethane foam is associated with particles to a much lower degree (3) than the $75 \%$ particulate fraction of MDI. With the higher total TDI concentration of $1000 \mathrm{ppb}$, compared with 40 ppb for MDI in our study, it is reasonable to assume that the particle concentration of the two isocyanates was similar. However, the much more pronounced effect on lung function during exposure to MDI indicates that particles generated during the thermal degradation of MDI-based polyurethane foam are more toxic per se than those of TDI-polyurethane foam. A recent study by Pauluhn et al (24) showed that guinea pigs experience an increase in respiratory rate when challenged with an MDI aerosol and that a 15 -minute inhalation exposure to MDI at $135 \mathrm{mg} / \mathrm{m}^{3}$, as either a $1.7-\mu \mathrm{m}$ or a 3.8- $\mu \mathrm{m}$ aerosol (mass median aerodynamic diameter), can sensitize guinea pig lungs. Together with our results, this finding indicates that the inhalation of thermal degradation products is a real occupational hazard, as it can both induce an acute reduction in lung function and lead to sensitization.

We conclude that the inhalation of thermal degradation products from MDI-polyurethane foam is likely to be more hazardous than the inhalation of such products produced by heated TDI-polyurethane foam. This finding is especially relevant because TDI is being replaced by other isocyanates, including MDI, in in- dustry. We suspect that the higher toxic response to degradation products from heated MDI-based polyurethane foam may be caused by MDI in particulate form.

\section{References}

1. Skarping G, Dalene M, Svensson B-G, Littorin M, Åkesson $\mathrm{H}$, Welinder $\mathrm{H}$, et al. Biomakers of exposure, antibodies, and respiratory symtoms in workers heating polyurethane glue. Occup Environ Med 1996;53:180-7.

2. Melin J, Johansson R, Bemgård A, Colmsjö A. Construction and evaluation of an aerosol generating apparatus for combustion products from polyurethane foam. Am Ind Hyg Assoc J 2000;61:166-73.

3. Melin J, Spanne M, Johansson R, Bohgard M, Skarping G, Colmsjö A. Characterization of thermally generated aerosols from polyurethane foam. J Environ Monit 2001;3:202-5.

4. Spanne M, Tinnerberg H, Dalene M, Skarping G. Determination of complex mixtures of airborne isocyanates and amines, part 1: liquid chromatography with ultraviolet metection of monomeric and polymeric isocyantes as their dibutylamine derivatives. Analyst 1996;121:1095-9.

5. Tinnerberg H, Spanne M, Dalene M, Skarping G. Determination of complex mixtures of airborne isocyanates and amines, part 3: methylenediphenyl diisocyanate, methylenediphenylamino isocyanate and methylenediphenyldiamine and structural analogues after thermal degradation of polyurethane. Analyst 1997;122:275-8.

6. Bernstein IL. Respiratory allergy: clinical aspects. Toxicol In Vitro 1994;8:975-80.

7. Tornling G, Alexandersson R, Hedenstierna G, Plato N. Decreased lung function and exposure to diisocyanates (HDI and HDI-BT) in car repair painters: observations on re-examination 6 years after initial study. Am J Ind Med 1990;17: 299-310.

8. Tarlo SM, Liss GM, Dias C, Banks DE. Assessment of the relationship between isocyanate exposure levels and occupational asthma. Am J Ind Med 1997;32:517-21.

9. Sari-Minodier I, Charpin D, Signouret M, Poyen D, Vervloet D. Prevalence of self-reported respiratory symptoms in workers exposed to isocyanates. J Occup Environ Med 1999;41: $582-8$.

10. Ott MG, Klees JE, Poche SL. Respiratory health surveillance in a toluene di-isocyanate production unit, 1967-97: clinical observations and lung function analyses. Occup Environ Med 2000;57:43-52.

11. Mapp CE, Saetta M, Maestrelli P, Di Stefano A, Chitano P, Boschetto P, et al. Mechanisms and pathology of occupational asthma. Eur Respir J 1994;7:544-54.

12. Butcher BT, Mapp CE, Fabbri LM. Polyisocanates and their prepolymers. In: Bernstein IL, Chan-Yeung M, Malo J-L, editors. Asthma in the workplace. New York (NY): Marcel Dekker Inc; 1993:415-37.

13. Låstbom L, Lind P, Dalene M, Skarping G, Ryrfeldt A, Moldéus P. Toluene diisocyanate exposure of isolated, perfused, and ventilated guinea pig lung — uptake and reduction in lung. J Clean Technol Environ Toxicol Occup Med 1996;5: 103-13.

14. Låstbom L, Skarping G, Moldéus P, Ryrfeldt Å. Hexamethylene diisocyanate (HDI)-induced lung impairment: studies in 
isolated perfused and ventilated guinea pig lungs. Pharmacol Toxicol 1997;81:85-9

15. Låstbom L, Camner P, Ryrfeldt $\AA$. Acute lung toxicity of hexamethylene diisocyanate and toluene diisocyanate - a comparative study in isolated guinea pig lungs. Occup Hyg 1999;5:111-20.

16. Kennedy AL, Låstbom L, Skarping G, Dalene M, Ryrfeldt Å, Moldéus $\mathrm{P}$, et al. Analysis of the reactivity of $\left[{ }^{14} \mathrm{C}\right]$-toluene diisocyanate (TDI) in an isolated, perfused lung model. Chem Biol Interact 1995;98:167-83.

17. Spanne M, Tinnerberg H, Dalene M, Skarping G. Determination of complex mixtures of airborne isocyanates and amines, part 1: liquid chromatography with ultraviolet detection of monomeric and polymeric isocyanates as their dibutylamine derivatives. Analyst 1996;121:1095-9.

18. Spanne M, Grzybowski P, Bohgard M. Collection efficiency for submicron particles of a commonly used impinger. Am Ind Hyg Assoc J 1999;60:540-4.

19. Kröll F, Karlsson J-A, Nilsson E, Persson CGA, Ryrfeldt A. Lung mechanics of the guinea-pig isolated perfused lung. Acta Physiol Scand 1986;128:1-8.
20. Låstbom L, Boman A, Camner P, Ryrfeldt Å. Increased airway responsiveness after skin sensitisation to 3-carene, studied in isolated guinea pig lungs. Toxicology 2000;147:209-14.

21. Amdur MO, Mead J. Mechanics of respiration in unanaesthetized guinea pigs. Am J Physiol 1958;192:364-8.

22. Pauluhn J, Rungeler W, Mohr U. Phenyl isocyanate-induced asthma in rats following a 2-week exposure period. Fundam Appl Toxicol 1995;24:217-28.

23. Raab O, Yeh H-C, Newton GJ, Phalen RF, Velasquez DJ. Deposition of inhaled monodisperse aerosols in small rodents. In: Walton WH, editor. Inhaled particles IV: proceedings of an international symposium organized by the British occupational hygiene society; 1975 Sept 22-26; Edinburgh. Oxford: Pergamon Press; 1977. p 3-21.

24. Pauluhn J, Thiel A, Emura M, Mohr U. Respiratory sensitization to diphenyl-methane $4,4^{\prime}$-diisocyanate (MDI) in guinea pigs: impact of particle size on induction and elicitation of response. Toxicol Sci 2000;56:105-13

Received of publication: 13 October 2001 